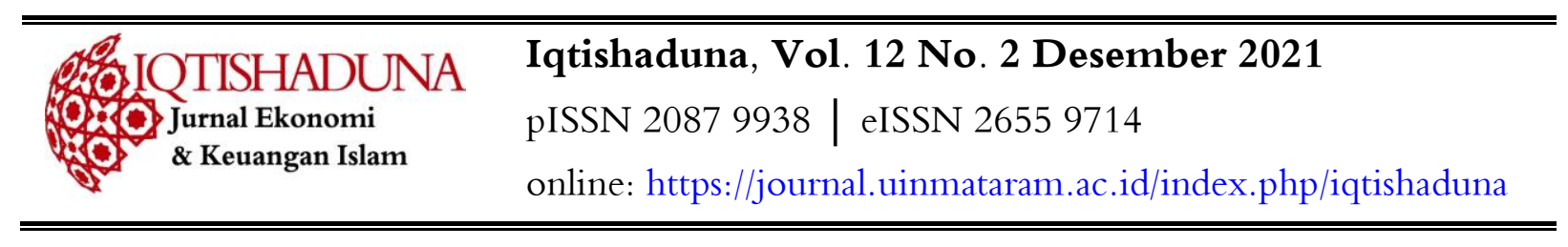

\title{
ANALISIS RASIO KEUANGAN BANK PEMBIAYAAN RAKYAT SYARIAH SEBELUM DAN SELAMA PANDEMI COVID-19
}

\author{
Wiwik Saidatur Rolianah ${ }^{1}$ Miftahurrahman ${ }^{2}$ Dewi Puspita Sari ${ }^{3}$ \\ Sekolah Tinggi Ekonomi Islam Kanjeng Sepuh Gresik Jawa Timur ${ }^{1}$ Sekolah Tinggi Agama Islam \\ An-Nawawi Purworejo ${ }^{2}$ Sekolah Tinggi Ekonomi Islam Kanjeng Sepuh Gresik Jawa Timur ${ }^{3}$ \\ wiwik@steikassi.ac.id¹ miftah131@gmail.com² dewi1918231033@steikassi.ac.id
}

\begin{abstract}
Abstrak
Pandemi Covid-19 sudah memberikan akibat yang signifikan pada segala kehidupan manusia, seperti di bidang pendidikan, kesehatan, ekonomi, dan lain-lain. Metode yang dipakai dalam penelitian berupa penelitian kuantitatif dengan memakai data sekunder dan mengumpulkannya lewat metode dokumentasi serta dianalisis memakai statistik desktiptif dan independent sample $t$-test. Data yang diambil sebelum Covid-19 berupa rasio keuangan CAR, ROA, ROE, NPF, FDR, dan BOPO di Bank Pembiayaan Rakyat Syariah pada bulan Maret 2019-Februari 2020 dan selama pandemi di bulan Maret 2020-Februari 2021. Hasil penelitian menyatakan nilai CAR dan ROE tidak normal sehingga tidak bisa melakukan uji independent $t$ sample. Kemudian dalam uji selanjutnya didapatkan nilai ROA $(0,15083)$ dan NPF (-0,22250) yang tidak terdapat perbedaan yang signifikan sedangkan pada rasio FDR $(2,17750)$ dan BOPO $(-2,81583)$ memiliki perbedaan yang signifikan antara sebelum dan selama pandemi covid-19 di Bank Pembiayaan Rakyat Syariah
\end{abstract}

Kata Kunci: Rasio Keuangan, Bank Pembiayaan Rakyat Syariah, Pandemi Covid-19

\section{PENDAHULUAN}

Penyebaran Covid-19 yang diinfokan Organisasi Kesehatan Dunia (World Health Organization) merupakan pandemic yang terjadi di seluruh dunia, termasuk Indonesia yang menunjukkan peningkatkan dari waktu ke waktu sehingga menimbulkan korban jiwa dan kerugian material (Pringgabayu et al., 2021; Tahliani, 2020). Di Indonesia pandemi ini diumumkan tanggal 02 Maret 2020 dengan terkonfirmasinya positif Covid-19 pada 2 warga Depok (Tahliani, 2020).

Kasus pandemi Covid-19 di Indonesia mempunyai dampak yang besar di bidang ekonomi, yang mana pemerintah Indonesia mengambil kebijakan untuk melakukan stabilitas ekonomi nasional agar bisa bertahan. Kebijakan ini diambil pemerintah, dan salah satunya kebijakan di dunia perbankan (Riftiasari \& Sugiarti, 2020).

Perbankan di Indonesia juga terancam dengan adanya pandemi Covid-19 sehingga pelaku industri menghadapi situasi yang sulit (Maulana et al., 2019). Perbankan memiliki kedudukan sangat penting untuk kemajuan ekonomi bangsa (Lasrin et al., 2016). Pada usaha penekanan 
persebaran dan meningkatnya korban akibat Covid-19 menyebabkan adanya kebijakan dari pemerintah Indonesia dalam penerapan protokol kesehatan dan batasan kegiatan yang melibatkan interaksi sosial tinggi di masyarakat. Adanya pembatasan ini dilaksanakan dengan tujuan penyelamatan nyawa masyarakat tetapi terdapat konsekuensi yang harus ditanggung berupa penurunan ekonomi. Jadi, industri terdampat pandemi Covid-19 dan batasan kegiatan termasuk pada sektor perbankan syariah (Pringgabayu et al., 2021).

Di bidang perbankan, adanya kebijakan physical distancing mengakibatkan sektor usaha tidak berjalan kemudian sektor ini melakukan pinjaman pada perbankan dan bisa mengalami kesulitan dalam melakukan pembayaran atau bisa menurunkan aktivitas usaha dan bisnis sehingga terdapat penurunan yang dialami kemudian menimbulkan kemampuan dari debitur dalam melakukan pembayaran (Sofyan, 2021). Jika hal tersebut terus terjadi maka akan mempengaruhi tingkat kolektibiltas kredit dari perbankan (Kholiq \& Rahmawati, 2020). Maka perbankan diharapkan bisa mengelola dan mempertahankan kinerja perbankan yang dilihat pada kinerja keuangan (Riftiasari \& Sugiarti, 2020).

Bank Pembiayaan Rakyat Syariah yang mempunyai fungsi sebagai lembaga intermediasi tentu dituntut bisa berinteraksi dengan orang banyak sehingga adanya pandemi Covid-19 menjadi tantangan tersendiri bagi lembaga ini (Sumadi, 2020). Rasio keuangan yang dilihat untuk memantau terkait kinerja perbankan syariah menjadi hal yang diperhatikan.

Kinerja keuangan yang dilihat dari rasio keuangan sebagai hasil presentasi yang diperoleh dari pembagian sistematis antara satu pos dengan pos lain yang mempunyai hubungan dalam segi keuangan (Yaqin et al., 2020). Rasio keuangan yang dipakai dalam penelitian ini berupa Capital Adequacy Ratio (CAR) sebagai rasio yang mengukur kecukupan modal dalam melakukan penunjangan aset (Riftiasari \& Sugiarti, 2020). Sedangkan di sisi profitabilitas sebagai kemampuan perusahaan dalam mendapatkan laba seoptimal mungkin untuk memakai sumber daya dalam bentuk modal yang dipunyai perusahaan pada suatu periode. Alat yang dipakai untuk mengukurnya berupa Return On Asset (ROA) dan Return On Equity (ROE), rasio ini mengukur atas profitabilitas dengan menunjukan efektifitas manajemen dalan melakukan pengelolaan aktivitas perusahaan dalam mendapatkan pendapatan (Dewi, 2016).

Terkait kinerja keuangan yang dijadikan dalam pengambilan keputusan secara terus menerus bagi pihak manajemen perusahaan dalam mencapai tujuan secara efektif dan efisien (Munawir, 2010). Maka terdapat beberapa tolak ukur kinerja perbankan yang bisa dilihat pada pengendalian pinjaman bermasalah (NPF) dan kemampuan untuk melakukan penyaluran dana pada pihak ketiga dalam pembiayaan (FDR) (Esomar, 2021). Dan Rasio BOPO menunjukkan hubungan dengan efisiensi perbankan saat mengoperasiokan usahanya terutama kegiatan 
pembiayaan, serta pembiayaan sendiri menyumbangkan pendapatan terbesar bagi perbankan syariah (Wibowo \& Syaichu, 2013).

Pada penelitian terdahulu juga mengkaji terkait CAR, FDR, NPF, dan profitabilitas perbankan syariah di masa pandemi antara lain Dematria Pringgabayu, Kurnia Fajar Afgani, dan Alda Ricederia (2021) yang menguji NPF dan FDR Bank Muamalat sebelum dan sesudah pandemi Covid-19. Temuannya menyatakan nilai rata-rata tahunan FDR Bank muamalat di masa pandemi lebih rendah jika dibandingkan dengan tahun sebelumnya (FDR tahun 2020 sebesar 74,13\% lebih rendah dari tahun 2018 dan 2019 senilai 75,78\%) sedangkan nilai rata-rata NPF tidak signifikan secara statistik (Pringgabayu et al., 2021). Selain itu Deby Aryanti Lasrin, Siti Hidayati, dan Yul Tito Permadhy (2021) yang menguji terkait faktor kinerja keuangan terhadap market share perbankan syariah (14 bank umum syariah) dan temuannya berupa NPF menunjukkan risiko pembiayaan berpengaruh negatif pada market share, profitabilitas tidak berpengaruh pada market share, dan permodalan berupa CAR berpengaruh positif terhadap market share (Lasrin et al., 2016).

Kemudian penelitian yang dilakukan oleh Ilhami dan Husni Thamrin (2021) yang menemukan bahwa secara keseluruhan dampak Covid-19 lada kinerja keuangan Perbankan Syariah di Indonesia, yang mana rasionya (CAR, ROA, NPF, dan FDR) tidak signifikan. Artinya perbankan syariah di Indonesia mampu bertahan di tengah pandemi Covid-19 (Ilhami \& Thamrin, 2021). Perbedaan temuan penelitian terdahulu dan mengacu pada keadaan lapangan disituasi pandemi Covid-19, maka peneliti berusaha untuk menganalisis keadaan Bank Pembiayaan Rakyat Syariah dengan membandingkan rasio keuangan berupa CAR, ROA, ROE, FDR, NPF, dan BOPO sebelum dan selama pandemi Covid-19.

\section{METODOLOGI}

Pendekatan yang dipakai pada penelitian ini berupa pendekatan kuantitatif dengan jenis penelitian deskriptif. Data penelitian yang dipakai berupa data sekunder yang didapat dari laporan Statistik Perbankan Syariah dari website resmi Otoritas Jasa Keuangan antara sebelum dan selama pandemi Covid-19. Data CAR, ROA, ROE, NPF, FDR, dan BOPO sebagai rasio keuangan dari bulan maret 2019 sampai februari 2021. Kemudian data yang dipakai dianalisis memakai statistik deskriptif dan independent sample t-test dengan bantuan program SPSS versi 26. Sebelum melaksanakan independent sample t-test dilaksanakan uji normalitas untuk mengetahui distribusi data penelitian. Jika datanya terdistribusi normal maka dilaksanakan independent sample t-test dalam mengetahui signifikansi rasio keuangan antara sebelum dan selama pandemi Covid-19. 


\section{HASIL DAN PEMBAHASAN}

Pandemi Covid-19 menjadi isu yang sangat mengkhawatirkan dalam berbagai bidang kehidupan baik dari segi kesehatan, politik, ekonomi, dan lain-lain. Penanggulangan yang dilaksanakan pada berbagai daerah sebagai bentuk usaha meminimalisir penyebaran tersebut, yang mana salah satunya lewat kebijakan lock down. Dan pemerintah lewat Otoritas Jasa Keuangan menyatakan Kebijakan Stimulus Perekonomian Nasional sebagai bentuk Kebijakan Counterylical Dampak Penyebaran Coronavirus Disease 2019 (POJK No. 11/POJK.03/2020) (Sumadi, 2020).

Bank Pembiayaan Rakyat Syariah sebagai lembaga intermediasi tentu bergantung dengan roda perekonomian yang bergerak sesuai dengan kegiatan masyarakat. Sehingga adanya kebijakan lock down mengakibatkan beberapa potensi yang ada tentu harus rela untuk kehilangan (Sumadi, 2020). Adanya pandemi Covid-19, tentu mempengaruh rasio keuangan pada Bank Pembiayaan Rakyat Syariah. Data yang dipakai sebagai rasio keuangan Bank Pembiayaan Rakyat Syariah adalah CAR, ROA, ROE, NPF, FDR, BOPO yang didapat dari laporan bulanan website resmi Otoritas Jasa Keuangan yang dipakai mulai maret 2019 sampai februari 2020 sebagai data sebelum bulan maret 2020 sampai februari 2021 sebagai data selama pandemi. Data ini kemudian akan dianalisis secara sistematis, dari analisis deskriptif kemudian dilanjutkan lewat uji normalitas dan independent sample t-test.

Eksistensi Bank Pembiayaan Rakyat Syariah mempunyai arti yang penting dalam pembangunan ekonomi yang berlandaskan syariah terutama terkait pemberian solusi untuk memberdayakan usaha kecil dan menengah serta menjadikan sebagai inti kekuatan perekonominan yang berlandaskan kerakyatan serta penyangga utama pada sistem perekonomian nasional (Tahliani, 2020). Hal tersebut, mengarahkan peran dari lembaga perbankan syariah sebagai lembaga intermediasi yang bisa menyelesaikan masalah fundamental yang terjadi pada pengusaha kecil dan menengah khususnya terkait permodalan. Bank Pembiayaan Rakyat Syariah tidak meliputi penyaluran modal namun untuk menangani kegiatan sosial juga (Rusydiana, 2016).

Dari hasil uji normalitas menunjukkan signifikansi uji Shapiro-Wilk mempunyai nilai < dari 0,05 sebelum ada pandemi Covid-19 dan > dari 0,05 untuk data yang terjadi selama pandemi. Hal tersebut menunjukkan terkait seluruh dari data penelitian sebelum pandemi tidak berditribusi normal sehingga tidak bisa dilanjutkan dengan uji independent t sampel pada nilai CAR. Rasio keuangan mempunyai hubungan pada kinerja keuangan, dan rasio ini dipakai untuk melakukan pengukuran kinerja keuangan perusahaan (Esomar, 2021). Penulis memakai rasio keuangan perbankan yang akan diteliti adalah Capital Adequact Ratio (CAR), Return On Asset (ROA), Return On Equity (ROE), Non Performing Finance (NPF), Financing to Deposit Ratio (FDR). 
Tabel 1. Hasil Uji Normalitas CAR

\begin{tabular}{|c|c|c|c|c|c|c|}
\hline \multicolumn{7}{|c|}{ Tests of Normality } \\
\hline & \multirow[b]{2}{*}{ Periode } & \multicolumn{3}{|c|}{ Kolmogorov-Smirnova } & \multicolumn{2}{|c|}{ Shapiro-Wilk } \\
\hline & & Statistic & $\mathrm{df}$ & Sig. & Statistic & Df Sig. \\
\hline \multirow[t]{2}{*}{ Nilai CAR } & Sebelum Pandemi Covid-19 & .322 & 12 & .001 & .654 & 12.000 \\
\hline & Selama Pandemi Covid-19 & .208 & 12 & .161 & .907 & 12.195 \\
\hline
\end{tabular}

Capital Adequacy Ratio (CAR) merupakan bentuk rasio kecukupan modal yang menggambarkan kemampuan dari perbankan untuk menyediakan dana untuk mengatasi adanya kemungkinan risiko kerugian (Fatimah et al., 2021). Rasio ini mempunyai manfaat untuk alat dalam pengukuran kecukupan modal yang dipunyai lembaga perbankan kemudian dipakai sebagai sarana mendapatkan resiko (bisa berupa kredit, dll) yang dibiayai oleh dana dari modal lembaga perbankan. Rumus yang dipakai untuk mengukur CAR sebagai berikut (Latifah \& Wirman, 2020):

\section{$C A R=\frac{\text { Modal Bank }}{\text { Aktiva Tertimbang Menurut Risiko }} \times 100 \%$}

Berdasarkan aturan standar penilaian di Peraturan BI maka (Peraturan BI No 6/10/PBI/2004 tentang Standar Rasio, n.d.):

Tabel 2. Standar Penilaian Rasio CAR

\begin{tabular}{|l|l|}
\hline Nilai Rasio & Predikat \\
\hline$>8 \%$ & Sehat \\
\hline $7,9 \%-8 \%$ & Cukup Sehat \\
\hline $6,5 \%-<7,9 \%$ & Kurang Sehat \\
\hline$<6,5 \%$ & Tidak Sehat \\
\hline
\end{tabular}

Tabel 3. Hasil Uji Normalitas ROA

\begin{tabular}{|c|c|c|c|c|c|c|c|}
\hline \multicolumn{2}{|c|}{ Tests of Normality } & & & & & & \\
\hline & & \multicolumn{3}{|c|}{ Kolmogorov-Smirnov ${ }^{a}$} & \multicolumn{3}{|c|}{ Shapiro-Wilk } \\
\hline & Periode & Statistic & Df & Sig. & Statistic & $\mathrm{Df}$ & Sig. \\
\hline \multirow[t]{2}{*}{ Nilai ROA } & Sebelum Pandemi Covid-19 & 211 & 12 & 146 & 937 & 12 & 461 \\
\hline & Selama Pandemi Covid-19 & 163 & 12 & $200^{*}$ & 942 & 12 & 522 \\
\hline
\end{tabular}

Berdasarkan dari hasil uji normalitas menunjukkan signifikansi untuk uji Shapiro-Wilk mempunyai nilai $>$ dari 0,05 sebelum ada pandemi Covid-19 $(0,461)$ dan selama ada pandemi $(0,522)$. Hal tersebut menunjukkan dari seluruh data penelitian antara sebelum dan selama ada 
pandemi Covid-19 berditribusi normal sehingga bisa dilanjutkan dengan uji independent $\mathrm{t}$ sampel pada nilai ROA.

Rasio profitabilitas dipakai untuk memperoleh profit lewat cara menunjukkan kemampuan dari seluruh asset yang sudah digunakan (Latifah \& Wirman, 2020). Jika tingkat profitabilitas tinggi maka menggambarkan terkait pengerjaan kegiatan operasional lembaga yang mampu bekerja efektif efisien (Latifah \& Wirman, 2020). Profitabilitas merupakan kemampuan suatu perusahaan dalam memperoleh keuntungan dari aktivitasnya. Rasio profitabilitas yang dipakai berupa return on asset (ROA), penurunan rasio ini mengakibatkan penurunan pangsa pasar perbankan syariah (Lasrin et al., 2016). ROA sebagai dari salah satu rasio profitabilitas dalam memperoleh pengembalian keuntungan yang bisa dilihat dari investasi untuk mendapat profit sesuai dengan hal yang diinginkan. Idealnya ROA perbankan syariah senilai 1,5\% dan jika perbankan memperoleh keuntungan di bawah dari nilai ditetapkan Bank Indonesia yang artinya perbankan belum bisa mengelola asset secara optimal (Maulana et al., 2019).

Profitabilitas terjadi sebab dampak dari ROA mendapatkan kenaikkan yang bisa dinikmati juga oleh pemegang saham, berikut ini rumus yang dipakai (Latifah \& Wirman, 2020):

$$
\text { ROA }=\frac{\text { Laba Sebelum Pajak }}{\text { Total Aktiva }} \times 100 \%
$$

Berikut ini standar penilaian rasio ROA (SK DIR BI No 30/21/KEP/DIR, n.d.):

Tabel 3. Standar Penilaian ROA

\begin{tabular}{|l|l|}
\hline Nilai Rasio & Predikat \\
\hline$>1,22 \%$ & Sehat \\
\hline $0,99 \%-1,21 \%$ & Cukup Sehat \\
\hline $0,77 \%-<0,98 \%$ & Kurang Sehat \\
\hline$<0,76 \%$ & Tidak Sehat \\
\hline
\end{tabular}

Tabel 4. Hasil Uji Normalitas ROE

\begin{tabular}{|c|c|c|c|c|c|c|c|}
\hline \multicolumn{2}{|c|}{ Tests of Normality } & & & & & & \\
\hline & & \multicolumn{3}{|c|}{ Kolmogorov-Smirnov $^{a}$} & \multicolumn{3}{|c|}{ Shapiro-Wilk } \\
\hline & Masa & Statistic & Df & Sig. & Statistic & Df & ig. \\
\hline \multirow[t]{2}{*}{ Nilai ROE } & Sebelum Pandemi Covid-19 & .323 & 12 & .001 & .738 & 12 & 002 \\
\hline & Selama Pandemi Covid-19 & .292 & 12 & .006 & .772 & 12 & 005 \\
\hline
\end{tabular}

Berdasarkan dari hasil uji normalitas menunjukkan signifikansi untuk uji Shapiro-Wilk mempunyai nilai < dari 0,05 sebelumada pandemi Covid-19 (0,002) dan selama pandemi $(0,005)$. 
Hal tersebut menggambarkan dari keseluruhan dari data penelitian antara sebelum dan selama pandemic Covid-19 tidak berditribusi normal sehingga tidak bisa melanjutkan uji independent t sampel pada nilai ROE.

Return On Equity (ROE) adalah rasio yang mempunyai keterkaitan laba bersih pada ekuitas dari pemegang saham. Rasio tersebut, bisa menentukan manajemen mana yang mampu untuk memberikan nilai tambah untuk pemegang saham. Berikut ini rumus yang dipakai untuk perhitungan ROE (Sullivan \& Widoatmodjo, 2021):

\section{ROE $=\frac{\text { Profit }}{\text { Total Equity }} \times 100 \%$}

Tabel 5. Hasil uji Normalitas NPF

\begin{tabular}{|c|c|c|c|c|c|c|c|}
\hline \multicolumn{8}{|c|}{ Tests of Normality } \\
\hline & \multirow[b]{2}{*}{ Periode } & \multicolumn{3}{|c|}{ Kolmogorov-Smirnov $^{\mathrm{a}}$} & \multicolumn{3}{|c|}{ Shapiro-Wilk } \\
\hline & & Statistic & $\mathrm{df}$ & Sig. & Statistic & $\mathrm{Df}$ & Sig. \\
\hline \multirow[t]{2}{*}{ Nilai NPF } & Sebelum Pandemi Covid-19 & 250 & 12 & .037 & .867 & 12 & .061 \\
\hline & Selama Pandemi Covid-19 & .152 & 12 & $.200^{*}$ & .919 & 12 & 279 \\
\hline \multicolumn{8}{|c|}{ *. This is a lower bound of the true significance. } \\
\hline \multicolumn{8}{|c|}{ a. Lilliefors Significance Correction } \\
\hline
\end{tabular}

Berdasarkan dari hasil uji normalitas menunjukkan signifikansi uji untuk Shapiro-Wilk mempunyai nilai $>$ dari 0,05 sebelum ada pandemi Covid-19 (0,061) dan selama ada pandemi $(0,279)$. Hal tersebut menggambarkan dari keseluruhan data penelitian antara sebelum dan selama ada pandemi Covid-19 berditribusi normal sehingga bisa dilanjutkan dengan uji independent $\mathrm{t}$ sampel pada nilai NPF.

Non Performing Finance (NPF) adalah rasio keuangan yang mempunyai keterkaitan resiko pembiayaan yang melekat di bank Islam. Jika rasio ini terjadi peningkatan yang tinggi maka kualitas pembiayaan perbankan semakin buruk, rumus yang digunakan pada rasio ini sebagai berikut (Latifah \& Wirman, 2020):

$$
N P F=\frac{\text { Pembiayaan Bermasalah }}{\text { Total Pembiayaan }} \times 100 \%
$$

Berikut ini standar penilaian rasio NPF (PBI NO 9/1/PBI/2007, n.d.):

Tabel 6. Standar Penilaian ROA

\begin{tabular}{|l|l|}
\hline Nilai Rasio & Predikat \\
\hline$\leq 2 \%$ & Sehat \\
\hline $2 \%-5 \%$ & Cukup Sehat \\
\hline $5 \%-8 \%$ & Kurang Sehat \\
\hline $8 \%-12 \%$ & Tidak Sehat \\
\hline
\end{tabular}


Tabel 7. Hasil Uji Normalitas FDR

\begin{tabular}{|c|c|c|c|c|c|c|}
\hline \multicolumn{7}{|c|}{ Tests of Normality } \\
\hline & \multirow[b]{2}{*}{ Periode } & \multicolumn{3}{|c|}{ Kolmogorov-Smirnov $^{a}$} & \multicolumn{2}{|c|}{ Shapiro-Wilk } \\
\hline & & Statistic & $\mathrm{df}$ & Sig. & Statistic & Df Sig. \\
\hline \multirow[t]{2}{*}{ Nilai FDR } & Sebelum Pandemi Covid-19 & 154 & 12 & $.200^{*}$ & .952 & \begin{tabular}{l|l}
12.668 \\
\end{tabular} \\
\hline & Selama Pandemi Covid-19 & 224 & 12 & .098 & .876 & 12.078 \\
\hline
\end{tabular}

Berdasarkan dari hasil uji normalitas menunjukkan signifikansi uji untuk Shapiro-Wilk mempunyai nilai $>$ dari 0,05 sebelum ada pandemi Covid-19 $(0,668)$ dan selama ada pandemi $(0,078)$. Hal tersebut menggambarkan dari keseluruhan data penelitian sebelum dan selama ada pandemi Covid-19 berditribusi normal sehingga bisa dilanjutkan dengan uji independent $\mathrm{t}$ sampel di FDR.

Financing to Deposite Ratio (FDR) adalah rasio yang dipakai dalam melaksanakan pengukuran likuiditas di lembaga keuangan perbankan syariah, rumus yang digunakan pada rasio ini sebagai berikut (Latifah \& Wirman, 2020):

$$
F D R=\frac{\text { Pembiayaan }}{\text { Total Dana Pihak Ketiga }} \times 100 \%
$$

Berikut ini standar penilaian rasio FDR (SK DIR BI No 30/21/KEP/DIR, n.d.):

Tabel 8. Standar Penilaian FDR

\begin{tabular}{|l|l|}
\hline Nilai Rasio & Predikat \\
\hline$\leq 94,75 \%$ & Sehat \\
\hline$>94,75 \%-\leq 98,50 \%$ & Cukup Sehat \\
\hline$>98,50 \%-\leq 102,25 \%$ & Kurang Sehat \\
\hline$>102,5 \%$ & Tidak Sehat \\
\hline
\end{tabular}

Tabel 9. Hasil Uji Normalitas BOPO

\begin{tabular}{|c|c|c|c|c|c|c|c|}
\hline \multicolumn{8}{|c|}{ Tests of Normality } \\
\hline & \multirow[b]{2}{*}{ Periode } & \multicolumn{3}{|c|}{ Kolmogorov-Smirnov ${ }^{a}$} & \multicolumn{3}{|c|}{ Shapiro-Wilk } \\
\hline & & Statistic & df & Sig. & Statistic & Df & Sig. \\
\hline \multirow[t]{2}{*}{ Nilai Bopo } & Sebelum Pandemi Covid-19 & .202 & 12 & .190 & .942 & 12. & .527 \\
\hline & Selama Pandemi Covid-19 & .193 & 12 & $.200^{*}$ & .931 & 12 & .393 \\
\hline \multicolumn{8}{|c|}{ *. This is a lower bound of the true significance. } \\
\hline \multicolumn{8}{|c|}{ a. Lilliefors Significance Correction } \\
\hline
\end{tabular}

Berdasarkan dari hasil uji normalitas menunjukkan signifikansi uji untuk Shapiro-Wilk mempunyai nilai $>$ dari 0,05 sebelum ada pandemi Covid-19 (0,527) dan selama ada pandemi 
(0,393). Hal tersebut menggambarkan dari keseluruhan data penelitian sebelum dan selama ada pandemi Covid-19 berditribusi normal sehingga bisa dilanjutkan dengan uji independent $\mathrm{t}$ sampel pada nilai BOPO.

Biaya operasional pendapatan operasional (BOPO), adalah rasio yang dipakai melakukan pengukuran kemampuan pendapatan operasional dalam menutupi biaya operasional. Jika rasio ini mengalami kenaikan maka menunjukkan perbankan kurang mampu dalam penekanan biaya dan pendapatan operasional yang tinggi sehingga berakibat pada kerugian perbankan yang kurang efisien pada pengelolaan usaha. Berikut ini rumus yang digunakan pada perhitungan BOPO (Riftiasari \& Sugiarti, 2020) :

$$
B O P O=\frac{\text { Biaya Operasional }}{\text { Pendapatan Operasional }} \times 100 \%
$$

Berikut ini standar penilaian rasio BOPO (SK DIR BI No 30/21/KEP/DIR, n.d.):

Tabel 10. Standar Penilaian BOPO

\begin{tabular}{|l|l|}
\hline Nilai Rasio & Predikat \\
\hline$<93,52 \%$ & Sehat \\
\hline $93,52 \%-94,73 \%$ & Cukup Sehat \\
\hline $94,73 \%-<95,92 \%$ & Kurang Sehat \\
\hline$>95,92 \%$ & Tidak Sehat \\
\hline
\end{tabular}

Maka dari uji normalitas dari rasio keuangan dalam penelitian ini yaitu CAR, ROA, ROE, NPF, FDR, BOPO yang bisa melanjutkan untuk melakukan independent sample t-test hanya rasio ROA, NPF, FDR, BOPO.

Tabel 11. Independent Sample t-test ROA

\begin{tabular}{|c|c|c|c|c|c|c|c|c|}
\hline & \multicolumn{7}{|c|}{ t-test for Equality of Means } \\
\hline & & \multirow[b]{2}{*}{$\mathrm{T}$} & \multirow[b]{2}{*}{ Df } & \multirow{2}{*}{$\begin{array}{l}\text { Sig. } \\
\text { tailed) }\end{array}$} & \multirow{2}{*}{$\begin{array}{l}\text { Mean } \\
\text { Difference }\end{array}$} & \multicolumn{2}{|c|}{$\begin{array}{ll} & 95 \% \\
\text { Std. } & \text { Error } \\
\text { Interval } & \text { Difference }\end{array}$} & $\begin{array}{l}\text { Confidence } \\
\text { of the }\end{array}$ \\
\hline & & & & & & Difference & Lower & Upper \\
\hline $\begin{array}{l}\text { Nilai } \\
\text { ROA }\end{array}$ & $\begin{array}{l}\text { Equal variances } \\
\text { assumed }\end{array}$ & 1.650 & 22 & .113 & 15083 & .09141 & -.03873 & .34040 \\
\hline & $\begin{array}{l}\text { Equal variances } \\
\text { not assumed }\end{array}$ & 1.650 & 15.802 & 2.119 & .15083 & .09141 & -.04314 & 34481 \\
\hline
\end{tabular}

Didapatkan nilai sig. (2-tailed) sebesar 0,113 > dari 0,05 maka tidak mempunyai perbedaan rasio keuangan berupa ROA yang signifikan sebelum dan selama ada pandemi covid19. Pada data mean difference menunjukkan angka 0,15083, yang mana menunjukkan selisih yang 
dialami di ROA pada saat sebelum dan selama pandemi. Dimana selisih perbedaan tersebut antara $-0,03873$ sampai 0,34040 .

ROA mengukur efektifitas perusahaan untuk mendapat profit dengan pemanfaatan aktiva yang dipunyai. Fungsi dari rasio ini melihat seberapa efektif perbankan dalam memakai aset dalam menghasilkan pendapatan. Jadi semakin besarnya ROA menggambarkan semakin baik kemampuan perbankan memperolehnya (Ilhami \& Thamrin, 2021). Rasio ini mendeskripsikan hasil pengembalian investasi dan produktivitas dari keseluruhan dana perusahaan yang dari modal sendiri ataupun pihak luar (Esomar, 2021).

Adanya dasar permodalan pada semua Lembaga keuangan bisa membantu depositor untuk mewujudkan presepsi terkait risiko terkait organisasi. Perbankan dianggap mempunyai pertimbangan kuat jika rasio kecukupan modal tinggi dan menunjukkan semakin aman dari yang namanya kebangkrutan (Sullivan \& Widoatmodjo, 2021). Profitabilitas bank saat mengalami kenaikan maka menunjukkan nasabah/masyarakat lebih percaya pada penyimpanan dana terhadap perbankan dan begitu juga sebaliknya. Hal ini bisa dikarenakan masyarakat mempertimbangkan adanya bagi hasil sehingga lebih menguntungkan (Lasrin et al., 2016).

Tabel 12. Independent Sample t-test NPF

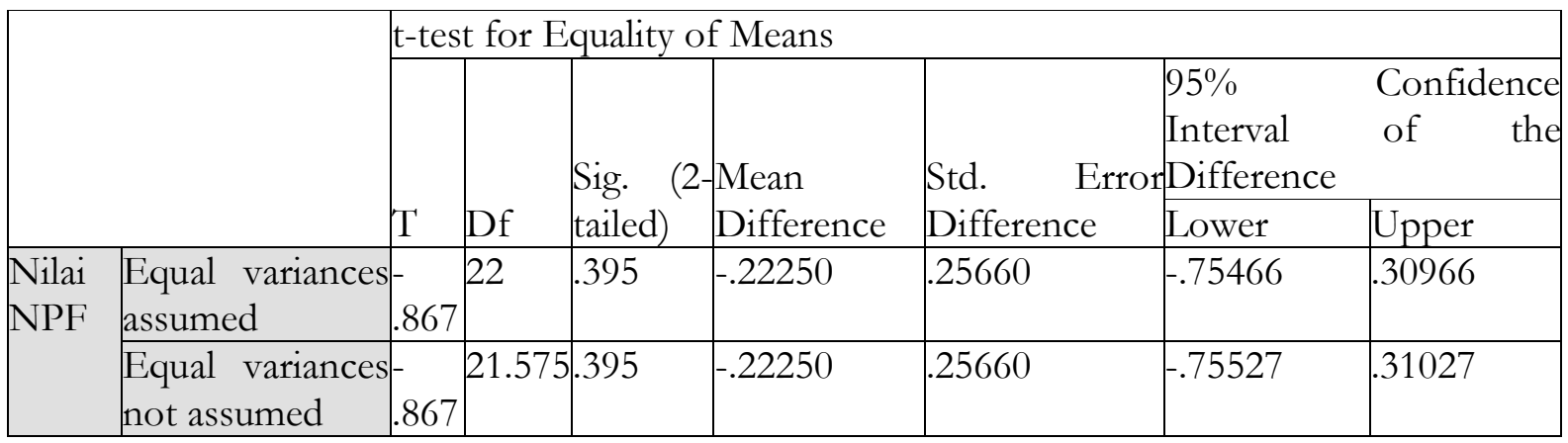

Didapatkan nilai sig. (2-tailed) sebesar $0,395>$ dari 0,05 maka tidak mempunyai perbedaan rasio keuangan berupa NPF yang signifikan pada saat sebelum dan selama ada pandemi covid-19. Pada data mean difference menunjukkan angka -0,22250, yang mana menunjukkan selisih yang terjadi pada NPF sebelum dan selama ada pandemi. Dimana selisih perbedaan tersebut antara -0,75466 sampai 0,30966.

NPF tinggi akan mengakibatkan pembesaran biaya maka mempunyai potensi pada kerugian perbankan. Jika rasio tinggi maka menunjukkan semakin buruk terkait kualitas pinjaman sehingga mengakibatkan jumlah pinjaman bermasalah semakin tinggi. Karena itu, perbankan bisa menanggung kerugian pada aktivitas operasional sehingga mempunyai pengaruh pada penurunan 
laba (Ilhami \& Thamrin, 2021). Rasio ini menggambarkan bentuk kegagalan dari debitur untuk melakukan pemenuhan kewajiban pada perbankan. Jadi NPF yang tinggi bisa memperbesar piutang yang tidaktertagih sehingga bisa mempengaruhi adanya penerimaan laba/kas perbankan sehingga mengalami penuruan dan berpotensi mengalami kerugian (Fauzi, 2018).

NPF adalah bentuk representasi pada risiko kredit pada perbankan, jadi semakin tinggi NPF menunjukkan semakin tinggi risiko kredit begitu juga sebaliknya. Berdasarkan Surat Edaran Otoritas Jasa Keuangan (OJK) No / seojk.03/2019 terkait sistem penilaian tingkat Kesehatan bank pembiayaan syariah berupa Peringkat 1 (NPF lebih kecil 7\%), peringkat 2 (7\% lebih kecil NPF dan lebih kecil sama dengan 10\%), peringkat 3 (10\% lebih kecil NPF dan lebih kecil sama dengan 13\%), peringkat 4 (13\% lebih kecil NPF dan lebih kecil sama dengan 16\%), dan peringkat 5 (NPF lebih kecil 16\%) (Pringgabayu et al., 2021). Jadi, tingkat NPF yang tinggi membuktikan kinerja dari perbankan syariah rendah sebab banyaknya permbiayaan bermasalah (Fatimah et al., 2021).

Tabel 13. Independent Sample t-test FDR

\begin{tabular}{|c|c|c|c|c|c|c|c|c|}
\hline & \multicolumn{7}{|c|}{ t-test for Equality of Means } \\
\hline & & \multirow[b]{2}{*}{$\mathrm{T}$} & \multirow[b]{2}{*}{ Df } & \multicolumn{2}{|c|}{ Sig. (2-Mean } & \multicolumn{3}{|c|}{$\begin{array}{ll} & 95 \% \\
\text { Std. } \quad \text { ErrorDifference } & \text { Interval }\end{array}$} \\
\hline & & & & tailed) & Difference & Difference & Lower & Upper \\
\hline $\begin{array}{l}\text { Nilai } \\
\text { FDR }\end{array}$ & $\begin{array}{l}\text { Equal variances } \\
\text { assumed }\end{array}$ & 1.55 & & .134 & 2.17750 & 1.39899 & -.72382 & 5.07882 \\
\hline & $\begin{array}{l}\text { Equal variances } \\
\text { not assumed }\end{array}$ & 1.55 & 618.497 & 7.137 & 2.17750 & 1.39899 & -.75601 & 5.11101 \\
\hline
\end{tabular}

Didapatkan nilai sig. (2-tailed) sebesar 0,045 yang < dari 0,05 maka terdapat perbedaan rasio keuangan berupa FDR signifikan pada saat sebelum dan selama pandemi covid-19. Pada data mean difference menunjukkan angka 2,17750, yang mana menunjukkan selisih yang terjadi pada FDR sebelum dan selama ada pandemi. Dimana selisih perbedaan tersebut antara $-0,72382$ sampai 5,07882.

FDR mengukur likuiditas pada besaran dana yang ditempatkan pada bentuk pinjaman dari dana yang dikumpulkan perbankan. Jika hasil yang didapatkan di atas target dan limit maka bisa saja perbankan sedang kesulitan likuiditas. Jadi semakin tinggi nilai FDR, artinya laba perusahaan mengalami peningkatan (Ilhami \& Thamrin, 2021). FDR sebagai rasio likuiditas mengukur jumlah dana pada bentuk pembiayaan/pinjaman yang berasal dari dana perbankan. Rasio ini melakukan pengukuran kemampuan dari perusahaan untuk melakukan pemenuhan 
kewajiban jatuh tempo dari sumber pendaan arus kas/aset likuid yang bisa diagunkan (Esomar, 2021).

Financing to Deposit Ratio (FDR) adalah rasio antara jumlah pembiayaan yang sudah disiapkan perbankan dengandana yang didapat. Menurut Bank Indonesia pada nilai standar dari FDR $80 \%$ sampai 110\%, dan jika rasionya dibawah 80\% maka dinilai tidak melaksanakan fungsi intermediasi dengan baik serta nilai diatas $110 \%$ dinilai likuiditas perbankan pada kategori buruk (Pringgabayu et al., 2021).

Tabel 14. Independent Sample t-test BOPO

\begin{tabular}{|c|c|c|c|c|c|c|c|c|}
\hline & \multicolumn{7}{|c|}{ t-test for Equality of Means } \\
\hline & & & & Sig. $\quad(2$ & Mean & Std. & $\begin{array}{l}95 \% \\
\text { Interval } \\
\text { rDifference }\end{array}$ & $\begin{array}{l}\text { Confidence } \\
\text { of the }\end{array}$ \\
\hline & & $t$ & Df & tailed) & Difference & Difference & Lower & Upper \\
\hline \multirow[t]{2}{*}{$\begin{array}{l}\text { Nilai } \\
\text { Bopo }\end{array}$} & $\begin{array}{l}\text { Equal variances } \\
\text { assumed }\end{array}$ & 4.359 & 22 & .000 & -2.81583 & .64591 & -4.15538 & -1.47629 \\
\hline & $\begin{array}{l}\text { Equal variances } \\
\text { not assumed }\end{array}$ & 4.359 & 16.233 & .000 & -2.81583 & .64591 & -4.18352 & -1.44815 \\
\hline
\end{tabular}

Didapatkan nilai sig. (2-tailed) sebesar 0,000 yang $<0,05$ maka terdapat perbedaan rasio keuangan berupa BOPO yang signifikan pada saat sebelum dan selama ada pandemi covid-19. Pada data mean difference menunjukkan angka -2,81583, yang mana menunjukkan selisih pada BOPO antara saat sebelum dan selama pandemi. Dimana selisih perbedaan tersebut antara 4,15538 sampai -1,47629.

Pasal 6 peraturan POJK Nomor 11/POJK.03/2020 terkait Stimulus Perekonomian Nasional sebagai Kebijakan Countercyclical Dampak Penyebaran adanya Corona Virus Disease 2019 yang berlaku buat kredit / pembiayaan yang memeuhi persyaratan berikut ini (POJK Nomor 11/POJK.03/2020 tentang Stimulus Perekonomian Nasional sebagai Kegiatan Countercyclical Dampak Penyebaran Corona Virus Disease 2019, 2020): memberikan pada debitur yang terdampak penyebaran corona virus disease 2019 (Covid-19) termasuk debitur usaha mikro kecil, dan menengah; dan menrestrukturisasi setelah debitur terdampak penyebaran corona virus disease 2019 (Covid-19) termasuk debitur usaha mikro, kecil, dan menengah.

Menurut Pratiwi, rasio BOPOadalah rasio yang bisa mengatur biaya lewat pendapatan sehingga bisa diketahui tingkat efisiensi menjadi kinerja dari ukuran manajemen (Yaqin et al., 2020). Jadi, dari hasil uji SPSS terkait rasio keuangan pada Bank Pembiayaan Rakyat Syariah pada BOPO yang terjadi perbedaan yang signifikan antara sebelum dan selama pandemic Covid-19. 


\section{SIMPULAN}

Berdasarkan hasil penelitian yang dilakukan terkait rasio keuangan Bank Pembiayaan Rakyat Syariah yaitu CAR, ROA, ROE, NPF, dan FDR yang dilakukan uji normalitas sebagai prasyarat dalam melaksanakan uji independent t sample. Hasil menunjukkan rasio ROA, NPF, FDR, dan BOPO bisa lanjut ke uji selanjutnya sedangkan yang lain tida, dan hasil menunjukkan pada rasio ROA dan NPF tidak mempunyai pengaruh yang signifikan antara sebelum (Maret 2019-Februari 2020) dan selama pandemi (Maret 2020-Februari 2021) sedangkan pada rasio FDR dan BOPO menunjukkan pengaruh yang signifikan antara perbedaan sebelum dan selama. Maka untuk Bank Pembiayaan Rakyat Syariah bisa melakukan pemfokusan yang lebih pada rasio ini selama pandemi Covid-19.

\section{REFRENSI}

Dewi, P. E. D. M. (2016). Pengaruh Rasio Likuiditas, Rasio Profitabilitas, Rasio Aktivitas, Rasio Solvabilitas, dan Rasio Nilai Pasar terhadap Return Saham. JLA: Jurnal Ilmiah Akuntansi, 1(2). https://doi.org/http://dx.doi.org/10.23887/jia.v1i2.9988

Esomar, M. J. F. (2021). Analisa Dampak Covid-19 terhadap Kinerja Keuangan Perusahaan Pembiayaan di Indonesia. Jurnal Bisnis, Manajemen, Dan Ekonomi, 2(2). https://doi.org/10.47747/jbme.v2i2.217

Fatimah, A., Fasa, M. I., \& Suharto. (2021). Analisis Kinerja Keuangan, Dampak Merger 3 Bank Syariah BUMN dan Strategi Bank Syariah Indonesia (BSI) dalam Pengembangan Ekonomi Nasional. JMB, 34(1).

Fauzi, A. (2018). Kredit Macet, NPL dan Pengaruhnya terhadap Kinerja Perusahaan pada Perusahaan Pembiayaan. JUMABIS: Jurnal Manajemen Dan Bisnis, 2(1).

Ilhami, \& Thamrin, H. (2021). Analisis Dampak Covid 19 terhadap Kinerja Keuangan Perbankan Syariah di Indonesia. Jurnal Tabarru': Islamic Banking and Finance, 4(1). https://doi.org/10.25299/jtb.2021.vol4(1).6068

Peraturan BI No 6/10/PBI/2004 tentang Standar Rasio.

Keuangan, O. J. (n.d.). Statistik Perbankan Syariah. https://www.ojk.go.id/id/kanal/syariah/datadan-statistik/statistik-perbankan-syariah/default.aspx

Kholiq, A., \& Rahmawati, R. (2020). Dampak Implementasi Restrukturisasi Pembiayaan terhadap Likuiditas Bank Syariah pada Situasi Pandemi Covid-19. El-Barka: Journal of Islamic Economics and Business, 3(2). https://doi.org/10.21154/elbarka.v3i2.2472

Lasrin, D. A., Hidayati, S., \& Permadhy, Y. T. (2016). Analisis Faktor-Faktor Kinerja Keuangan yang Mempengaruhi Market Share Perbankan Syariah di Indonesia. KORELASI, 7(2). 
Rolianah dkk. Title Analisis Rasio Keuangan Bank Pembiayaan Rakyat Syariah

https://doi.org/10.15408/akt.v7i2.2675

Latifah, L., \& Wirman. (2020). Pengaruh Capital Adequacy Ratio , Non-Performing Financing dan Financing To Deposite Ratio terhadap Return on Asset pada PT Bank Syariah Mandiri Periode 2013-2020. Ad-Deenar: Jumal Ekonomi Dan Bisnis Islam, 5(1). https://doi.org/10.30868/ad.v5i01.1224

Maulana, P., Dwita, S., \& Helmayunita, N. (2019). Pengaruh CAR, NPL, LDR dan BOPO terhadap Return On Assets (ROA) Pada Bank Terdaftar di Bursa Efek Indonesia Tahun 2017-2019. JEA: Jurnal Ekesplorasi Akuntansi, 6(1).

Munawir. (2010). Analisa Laporan Kenangan. Salemba Empat.

PBI NO 9/1/PBI/2007.

POJK Nomor 11/POJK.03/2020 tentang Stimulus Perekonomian Nasional sebagai Kegiatan Countercyclical Dampak Penyebaran Corona Virus Disease 2019, (2020).

Pringgabayu, D., Afgani, K. F., \& Ricederia, A. (2021). Perbedaan NPF dan FDR Bank Muamalat antara Sebelum dan Selama Pandemi Covid-19. Jurnal Maps (Manajemen Perbankan Syariah), 4(2). https://doi.org/10.32483/maps.v4i2.59

Riftiasari, D., \& Sugiarti. (2020). Analisis Kinerja Keuangan Bank Bca Konvesional dan Bank BCA Syariah Akibat Dampak Pandemi Covid-19. JMB: Jurnal Manajemen Bisnis, 33(2).

Rusydiana, A. S. (2016). Analisis Masalah Pengembangan Perbankan Syariah di Indonesia: Aplikasi Metode Analytic Network Proces. Jurnal Bisnis Dan Manajemen, 6(2). https://doi.org/https://doi.org/10.15408/ess.v6i2.3573

SK DIR BI No 30/21/KEP/DIR.

Sofyan, M. (2021). Kinerja BPR dan BPRS pada Masa Pandemi COVID-19. The 2nd Seminar Nasional ADPI Mengabdi Untuk Negeri Pengabdian Masyarakat Di Era New Normal, 2(2).

Sullivan, V. S., \& Widoatmodjo, S. (2021). Kinerja Keuangan Bank Sebelum dan Selama Pandemi (Covid - 19). Jurnal Manajerial Dan Kewirausahaan, III(1).

Sumadi. (2020). Menakar Dampak Fenomena Pandemi Covid-19 terhadap Perbankan Syariah. Jurnal Hukum Ekonomi Syariah, 3(2). https://doi.org/10.30595/jhes.v0i1.8761

Tahliani, H. (2020). Tantangan Perbankan Syariah dalam Menghadapi Pandemi Covid-19. Madani Syariah, 3(2). https://stai-binamadani.e-journal.id/Madanisyariah/article/view/205

Wibowo, E. S., \& Syaichu, M. (2013). Analisis Pengaruh Suku Bunga, Inflasi, CAR, BOPO, NPF terhadap Profitabilitas Bank Syariah. Diponegoro Journal of Management, 2(2).

Yaqin, M. A., Susyanti, J., \& Priyono, A. A. (2020). Pengaruh Perputaran Kas, Loan to Deposit Ratio (LDR), Biaya Operasional Pendapatan Operasional (BOPO) dan Total Asset Turnover (TATO) terhadap Profitabilitas. E-Jurnal Riset Manajemen, 110(9). 